\title{
Developing measurement scales of collaboration in shipping logistics
}

\section{Kim, CS}

http://hdl.handle.net/10026.1/15739

10.1080/13675567.2020.1770708

International Journal of Logistics Research and Applications

Informa UK Limited

All content in PEARL is protected by copyright law. Author manuscripts are made available in accordance with publisher policies. Please cite only the published version using the details provided on the item record or document. In the absence of an open licence (e.g. Creative Commons), permissions for further reuse of content should be sought from the publisher or author. 


\section{Chang Soo Kim ${ }^{\mathrm{a}}$, John Dinwoodie ${ }^{\mathrm{b}}$ and Saeyeon $\mathrm{Roh}^{\mathrm{b} *}$}

${ }^{a}$ Department of International Trade, College of Economics and International Trade, Pusan National University, South Korea; ${ }^{b}$ Department of International Shipping, Logistics and Operations, Plymouth Business School, Plymouth University, Plymouth, U.K.

\section{"Saeyeon Roh}

Lecturer in International Logistics, Plymouth Business School, Faculty of Arts, Humanities and Business, Cookworthy Building 405G, Plymouth University, Drake Circus, Plymouth, PL4 8AA, Devon, UK

*Corresponding author: Email: saeyeon.roh@plymouth.ac.uk 


\title{
Developing Measurement Scales of Collaboration in Shipping Logistics
}

\begin{abstract}
This study aims to identify and develop the practical elements of supply chain collaboration (SCC) within the context of shipping logistics. These elements offer maritime policymakers fundamental principles on which to formulate policies to enhance collaboration between shippers and shipping companies. Constructs and their corresponding items are derived from extant SCM literature reinforced with input by shipping experts, to create scales applicable in shipping. Content validity of the instrument is assured through two rounds of Q-sorting and a pilot test, and procedures which generated the final 24 items are noteworthy. The instrument scales developed invite further studies to measure collaboration in shipping logistics and the procedures used to develop the measurement instrument for collaboration are relevant to other fields and disciplines.
\end{abstract}

Keywords: supply chain collaboration; scale development; shipping company; shipper; Qsorting

\section{Introduction}

Worldwide, globalised commerce has impacted the volume and network of international seaborne transport. By volume, four-fifths of global merchandise trade moves by sea (UNCTAD 2016) and by value, three-fifths of commodities carried internationally rely on container shipping (Mason and Nair 2012). As the World Trade Organisation and Free Trade Agreements open-up the global economy, the shipping industry faces periodic cyclical crises (Kuo, Lin, and Lu 2017) which are brought about by the imbalance between demand and supply of shipping spaces.

From the demand side, the globalization of manufacturers has caused shipping companies to deliver goods globally. To provide the globalized services, shipping companies incurred increased costs (Midoro, Musso, and Parola 2005) whereas the demand for the services has not developed fully because of sluggish global economic growth. 
In the supply side of shipping spaces, to cope with the increased costs from the globalized services and intensified competition from new carriers (Slack, Comtois and McCalla, 2002), shipping companies have sought new forms of cooperation such as global alliances (Midoro, Musso, and Parola 2005). To date there are three giant alliances: 2M+HMM (MEARSK, MSC, and HMM), OCEAN (CMA-CGM, COSCO, and Evergreen), and THE (Hapag-Lloyd, Yang Ming, and One) (KMI 2017). Alliances promulgated reduced costs and risks which prompted carriers to accentuate price advantages rather than to adopt a differentiation strategy for their services and capabilities (Maloni, Gligor, and Lagoudis 2016). Because of extreme difficulty in keeping stable freight rates in the very competitive business environment (Midoro, Musso, and Parola 2005), shipping lines have become price-takers, who survive by reducing costs (Notteboom, Rodrigue, and De Monie 2010). Survival strategies for major carriers now embrace scale economies which herald larger vessels and mergers and acquisitions (Midoro, Musso, and Parola 2005). Overcapacity to outperform competitors has caused more fierce competition, reduced profitability, and hampered the recovery of shipping markets (Kuo, Lin and Luo 2017). Due to the demand-supply mismatch average freight rate on the Asia-Europe route sharply decreased from $\$ 1,771 /$ TEU to $\$ 815 /$ TEU between 2010 and 2018 (KMI 2018).

From the stance of a traditional economy, shipping can be characterized by an oligopolistic market in which alliances are in the minority competing with numerous other shippers who are price takers. However, as mentioned above, the fierce competition among the three giants produced a sharp glut of shipping spaces which promulgated a tremendous increase in shipping companies reliant on only a price differentiation strategy. Consequently, shippers exhibited more power than shipping companies (Golicic 2007). Shipper strength is evident when shippers severely curtail transport budgets (Stopford 2009). Furthermore, the sluggish demand and the overcapacity created 
pressures to fill ships with freight (Midoro, Musso, and Parola 2005). Shipping companies commit more to their relationships with shippers (Golicic 2007) to maintain contracts with shippers.

In this highly competitive and shipper-dominated market, shipping company survival strategies may prioritize attempts to create and maintain freight transportation contracts with shippers for filling ship space. Because the income of shipping companies is only reliant on shippers who can easily change shipping companies, shipping companies may not succeed if shippers do not adopt a collaborative attitude towards them (Talley and $\mathrm{Ng} 2013$ ). The collaborative attitude of shippers such as guaranteeing reasonable profits, sharing additional costs, and long term contracts can be a great help to shipping lines which have struggled to cope with their predicament. Accordingly, interest in the necessity for collaborative relationships between shipping companies and shippers has burgeoned.

Sporadic historical measures of supply chain collaboration (SCC) (Simatupang and Sridharan 2004) typically featured supply chain (SC) relationships involving either suppliers and manufacturers or suppliers and retailers (Hudnurkar, Jakhar, and Rathod 2014). Furthermore, conceptualization of collaboration focused on process integration rather than its multiple traits (Cao et al. 2010). Most studies of collaboration between shippers and carriers feature inland logistics (Fugate, Davis-Sramek, and Goldsby 2009; Gardner, Cooper, and Noordewier 1994; Gibson, Ruttner, and Keller 2002; Golicic, 2007; Kleinsorge, Schary, and Tanner 1991; Zsidisin, Voss, and Schlosser 2007) offering few reliable and generally accepted instruments with which to measure SCC within maritime logistics (Seo, Dinwoodie, and Roe 2015; 2016). Accordingly, this study aims to identify and develop practical and suitable elements to characterize SCC in shipping logistics because items of SCC in other fields cannot be adopted in shipping per se and should be adapted properly. Through the development process, this study helps to understand what SCC is in relation to what shipping companies expect from shippers. Additionally, this study introduces a rigorous 
procedure to develop a measurement instrument for SCC based on interviews with industrial experts, Q-sorting, and pilot testing for the adoption of suitable items and constructs. The items of SCC developed in this study offer maritime policymakers some fundamental principles and ideas on which to formulate policies to enhance collaboration between shippers and shipping companies.

\section{Literature Review}

\section{Collaboration in Supply Chain Management and Logistics}

Cooperation and collaboration between shippers and carriers have emerged including key components of an effective logistics partnership (Gibson, Rutner, and Keller 2002). Gardner, Cooper, and Noordewier (1994) identify the components of win/win partnership relationships such as "relationship extendedness" (loyalty and long-term expectations) and sharing of benefits and burdens between shippers and carriers/warehousers. Stank, Keller, and Closs (2001) find that internal collaboration affects directly logistical service performance and external collaboration influences the performance indirectly through its direct effect on internal collaboration. Gibson, Rutner, and Keller (2002) note that successful partnerships between carriers and shippers include trust, effectiveness, shared risk and reward, and information sharing. Zsidisin, Voss, and Schlosser (2007) show that closer relationships between shippers and carriers such as communication, trust and mutual dependence significantly influence the willingness of carriers to commit assets to shippers. More recently, Song and Lee (2012) found that cooperation facilitates knowledge acquisition, which can in turn positively impact maritime logistics value.

\section{Collaboration in Maritime Logistics and Shipping}

The concept of integration underpins maritime logistics (Panayides and Song 2009) and the main purpose of integration is to achieve operational efficiencies and strategic effectiveness in a SC through collaboration between SC members (Richey et al 2010). Coordination and collaboration 
among SC members are referred to as external integration (Gimenez and Ventura 2005). Song and Panayides (2008) invite empirical study including the concepts of information sharing and trust to measure port and terminal supply chain integration (SCI). Frémont (2008) argues that horizontal integration among shipping lines, terminal operators or forwarding agents/logistics providers exists

evidently whereas vertical integration is limited. In a case study of coal SC in the maritime industry, Nassirnia and Robinson (2013) note that cooperation between all SC members and SCI can maximize benefits and value chain increments. However, the studies on SCI in maritime transport are limited (Lam 2011) with little conceptualisation and measurement of integration across SCs (Panayides and Song 2009). Recently, Heaver (2015) and Seo, Dinwoodie, and Roe (2015) adapted explicitly the concept of collaboration to maritime logistics, the latter identifying that information sharing, knowledge creation, goal similarity, decision harmonisation and joint SC performance measurement comprise major components of SCC in maritime logistics. In contrast, although Lam and Zhang’s (2014) enhanced logistics service provider framework highlighted similar SC performance criteria, any conceptualisation of collaboration remained implicit. Heaver (2015) reveals that under fierce competition and uncertainties arising from globalisation, new collaborative relationships among international logistics parties for the improvement of efficiency are emerging. However, few reliable and generally accepted instruments are available to measure SCC in maritime logistics (Seo, Dinwoodie, and Roe 2015). Literature conceptualising and measuring comprehensive and practical collaboration between shippers and shipping companies is scarce.

\section{Conceptualization of Collaboration}

\section{Construction of collaboration}

SCC implies "two or more chain members working together to create a competitive advantage through sharing information, making joint decisions and sharing benefits which result from greater 
profitability of satisfying end customer needs than acting alone" (Simatupand and Sridharan, 2005, 45). Cao and Zhang $(2011,166)$ define SCC as "a partnership process where two or more autonomous firms work closely to plan and execute SC operations towards common goals and mutual benefits". "SCC is rooted in a paradigm of collaborative advantage... rather than competitive advantage" (Cao and Zhang, 2011, 164). Efficient collaboration can resolve the bullwhip effect arising from distorted information on demand (Li 2012). The collaborative relationship can also lead to benefits of sharing risks (Kogut 1988), acquisition of complementary resources (Park, Mezias, and Song 2004), reduced transaction costs and enhanced productivity (Kalwani and Narayandas 1995) and improved performance (Mentzer, Foggin, and Golicic 2000; Cao and Zhang 2011). As a third alternative to hierarchies and markets, SCC helps firms to diminish the costs related to opportunism and companies to avoid the risk of internalisation of an activity which may not be commensurate with their competencies (Cao and Zhang 2011).

However, "a wide range of theoretical perspectives result in an equally wide variety of definitions and understandings of the meaning of collaboration." (Thomson, Perry, and Miller 2009, 23). Unsurprisingly, SCC has many definitions (Hudnurkar, Jakhar, and Rathod 2014). Diverse and numerous concepts representing collaboration create a requirement to organize relevant constructs. As such, each sub-construct of collaboration is derived from the integration of several concepts considered to have a similar meaning or to explain the same construct. For example, information sharing, communication, and formalization were considered to merge into transparency. In accordance with the same procedure, sub-constructs of collaboration are identified to involve transparency, fairness, mutuality, trust and sustainability.

In this context, collaboration is defined as a business partnership process whereby partners aim to sustain long-term cooperative relationships such as transparency, fairness, and mutuality based on trust between them. 


\section{Concepts of collaboration}

Transparency implies the extent to which a partner has an open and transparent relationship with the other partner such as smooth communication, information sharing, and clear setting-up of the relationship through prior agreement. Hence, transparency involves the concepts of information sharing, communication, and formalization. Cao et al $(2010,6617)$ define information sharing as "the extent to which a firm shares a variety of relevant, accurate, complete and confidential ideas, plans, and procedures with its SC partners in a timely manner." The sharing of information among partners is a primary form of collaboration and the exchange of private data among partners is required to establish an efficient SC (Kumar and Nath Banerjee 2014; Jayaraman, Ross, and Agarwal 2008). Realistic, up to date, and detailed information exchange can lead to better decisionmaking and SC efficiency (Min et al 2005). Collaborative communication is "the contact and message transmission process among SC partners in terms of frequency, direction, mode, and influence strategy" (Cao et al 2010). Collaborative communication has the characteristics of higher frequency, more bidirectional flows, better information mode, and enhanced indirect influence (Mohr and Nevin 1990). Formalization is "the extent to which decision making is regulated by explicit rules and procedures" (Dwyer and Oh 1987, 349). High formalization implies formal rules and standardized polices affect decisions and working relationship for an extended period between SC members. Formalization can create behavioral expectations and standard practices are established through eliminating ambiguity and clarifying priorities between SC members (Daugherty et al 2006). Thus, well-established formalization can enhance transparency between parties.

Fairness signifies the extent to which a partner treats the other partner company fairly and justly such as no discrimination between the other partner companies, observation of related regulations and laws, and guarantee of reasonable and just profits for the other partner company. 
The other terminologies of fairness are justice (Konoysky 2000) and reciprocity (Bensaou 1997). Fairness can be conceptualized within collaborative buyer-supplier relationships in a SC (Hornibrook, Fearne, and Lazzarin 2009). A vulnerable party in a SC is sensitive to infringement of fairness by its more powerful partners. Fairness includes procedural justice and distributive justice (Kumar, Scheer, and Steenkamp 1995; Duffy, Fearne, and Hornibrooke 1995, 55). "Procedural justice refers to when a firm perceives the development and administration of relationship policies to be fair and equitable" (Griffith, Harvey, and Lusch 2006, 91). That is, procedural justice implies how fairly a firm and its personnel deal with its partner firm. Procedural justice concentrates on the fairness of procedures itself by which decisions are made and on the attitudes of people affected by those decisions. "Distributive justice refers to how equitable the firm perceives the distribution of relationship resources relative to inputs" (Griffith, Harvey, and Lusch 2006, 91). Successful partnerships depend on whether participants share gains and losses equitably and fairly or not (Cao et al 2010).

Mutuality implies the extent to which a partner treats the other partner as an equal business partner and is willing to support the other partner through mutual understanding. Such notions as goal congruence, resource sharing, joint problem solving, joint performance measurement, joint knowledge creation can be included within mutuality. Goal congruence implies "the extent to which SC partners perceive their own objectives are satisfied by accomplishing the SC objectives" and “congruence signifies that SCC requires a degree of mutual understanding and agreement across firm attributes, values, beliefs, and practices" (Cao et al, 2010, 6618). Resource sharing refers to "the process of leveraging capabilities and assets and investing in capabilities and assets with SC partners." (Cao et al, 2010, 6620). Sustainable collaborations must be maintained by considerable mutual resource investments and therefore, non-financial investments such as time, money, training, and technology as well as financial investments are essential. Sufficient commitment of 
management time prospers in collaborative relationships (Min et al 2005). Problem solving implies settling matters like disagreements and conflicts between partners (Lusch and Brown 1996), and unexpected disasters (Kumar and Nath Banerjee 2014). Mutually advanced process improvement can be caused through joint problem-solving procedures (Min et al 2005). Measuring performance of collaboration is required to encourage suitable behaviors and to make effective collaboration possible (Slone 2004). Monitoring and measuring performance properly can assure the success of collaborative efforts (Min et al 2005; Wandfluh, Hofmann, and Schoensleben 2016). Joint knowledge creation can be defined as the extent to which SC partners better understand and react to a market and an environment by collaboration (Malhotra, Gosain, and Sawy 2005). New knowledge creation has been a main purpose of collaboration (Hardy, Phillips, and Lawrence 2003).

Trust refers to the extent to which a partner company can be trusted in terms of trustworthiness, good faith and fulfilment of obligations. Trust is the extent to which partners consider each other as believable (Ganesan 1994). Trust can be considered as a belief or an expectation of a partner that the other partner will not take advantage of its vulnerability caused by the acceptance of risk inevitably inherited in their relationship or transaction (Lane 2000). Credibility and honesty are two components of trust (Eyuboglu, Ryu, and Tellefsen 2003) whereas credibility and benevolence are two dimensions to measure trust (Wang, Siu, and Barnes 2008). Trust can result in decreasing a variety of costs related to ex ante negotiation, conclusion of a contract as well as ex post transactions (Ryu, Park, and Min 2007). Trust can contribute to decreasing anxiety and uncertainty between partners (Wang, Siu, and Barnes 2008) and reducing transaction costs among them (Ganesan 1994; Kwon and Suh, 004). Trust can play a role of restraint of the other partner's opportunistic behavior and make a dominant partner refrain from exerting its power over the weaker partner (Ganesan 1994; Mei and Dinwoodie 2005). 
Sustainability signifies the extent to which a partner sustains and strengthens continuously its cooperative relationships with the other partner. Sustainability contains the concepts of commitment and long-term orientation. Sustainability is a similar concept to Gardner, Cooper, and Noordewier's (1994) "relationship extendedness" indicating loyalty and long-term expectations. Commitment refers to "an implicit or explicit pledge of relational continuity between exchange partners" (Dwyer, Schurr, and Oh 1987, 19). In the context of commitment, "the parties are tolerant of each other's deficiencies (within reason) and that each will cooperate and not act opportunistically" (Min et al 2005, 243). "A committed partner wants the relationship to endure indefinitely and is willing to work at maintaining it" (Morgan and Hunt 1994, 23). Long-term orientation implies the desire of a partner towards having a long-term relationship with one partner (Ganesan 1994). Construction, maintenance and enhancement of long-term relationships with SC partners is required for effective SCM. The options and results of the current period are only concerns for parties with a short-term orientation whereas parties with a long-term orientation are interested in current and future outcomes as well as accomplishing future goals (Ganesan 1994). Long-term relationship between partners can promote diverse forms of collaborative behaviours (Kalwani and Narayandas 1995). Table 1 represents the composition of collaboration in this research.

Table 1. Conceptualisation of collaboration

\begin{tabular}{|c|c|c|}
\hline \multicolumn{2}{|c|}{ Components of collaboration } & Author \\
\hline \multirow[t]{3}{*}{ Transparency $(\mathrm{T})$} & Information sharing & $\begin{array}{l}\text { Sahin and Robinson (2002), Min et al. (2005), Cheng and Wu } \\
\text { (2005), Simatupang and Sridharan (2005), Ryu, Park, and Min } \\
\text { (2007), Cao et al. (2010), Chen et al. (2011), Cao and Zhang } \\
\text { (2011), Prajogo and Olhager (2012), Li (2012), Kumar and } \\
\text { Nath Banerjee (2014), Ramanathan and Gunasekaran (2014) }\end{array}$ \\
\hline & Communication & $\begin{array}{l}\text { Mohr and Nevin (1990), Min et al. (2005), Cao et al. (2010), } \\
\text { Cao and Zhang (2011), Kumar and Nath Banerjee (2014) }\end{array}$ \\
\hline & Formalisation & $\begin{array}{l}\text { Dwyer and Oh (1987), Min et al. (2005), Daugherty et al. } \\
(2006)\end{array}$ \\
\hline Fairness (F) & $\begin{array}{l}\text { Procedural justice and } \\
\text { distributive justice }\end{array}$ & $\begin{array}{l}\text { Kumar, Scheer, and Steenkamp (1995), Bensaou (1997), } \\
\text { Konovsky (2000), Duffy, Fearne, and Hornibrooke (2003), } \\
\text { Harland et al. (2004), Simatupang and Sridharan (2005), } \\
\text { Griffith, Harvey, and Lusch (2006), Maloni and Brown }\end{array}$ \\
\hline
\end{tabular}




\begin{tabular}{|c|c|c|}
\hline \multicolumn{2}{|c|}{ Components of collaboration } & Author \\
\hline & & $\begin{array}{l}\text { (2006), Hosoda and Disney (2006), Hornibrook, Fearne, and } \\
\text { Lazzarin (2009), Cao et al. (2010), Kim et al. (2010), Nassirnia } \\
\text { and Robinson (2013), Kumar and Nath Banerjee (2014) }\end{array}$ \\
\hline \multirow[t]{5}{*}{ Mutuality (M) } & Goal congruence & $\begin{array}{l}\text { Simatupang and Sridharan (2005), Cao et al. (2010), Kim et } \\
\text { al. (2010), Cao and Zhang (2011) }\end{array}$ \\
\hline & Resource sharing & $\begin{array}{l}\text { Min et al. (2005), Cao et al. (2010), Cao and Zhang (2011), } \\
\text { Kumar and Nath Banerjee (2014), Ramanathan and } \\
\text { Gunasekaran (2014) }\end{array}$ \\
\hline & Joint problem solving & $\begin{array}{l}\text { Lusch and Brown (1996), Min et al. (2005), Kumar and Nath } \\
\text { Banerjee (2014) }\end{array}$ \\
\hline & Joint performance measurement & $\begin{array}{l}\text { Slone (2004), Min et al. (2005), Kumar and Nath Banerjee } \\
\text { (2014) }\end{array}$ \\
\hline & Joint knowledge creation & $\begin{array}{l}\text { Malhotra, Gosain, and Sawy (2005), Cao et al. (2010), Cao } \\
\text { and Zhang (2011) }\end{array}$ \\
\hline Trust (Tr) & & $\begin{array}{l}\text { Dwyer, Schurr, and Oh (1987), Dwyer and Oh (1987), } \\
\text { Anderson and Narus (1990), Ganesan (1994), Kumar, Scheer, } \\
\text { and Steenkamp (1995), Eyuboglu, Ryu, and Tellefsen (2003), } \\
\text { Kwon and Suh (2004), Min et al. (2005), Ryu, Park, and Min } \\
\text { (2007), Wang, Siu, and Barnes (2008), Kim et al. (2010), Delai } \\
\text { and Takahashi (2011), Nyaga and Whipple (2011), Chen et al. } \\
\text { (2011), Kumar and Nath Banerjee (2014), }\end{array}$ \\
\hline Sustainability (S) & & $\begin{array}{l}\text { Dwyer, Schurr, and Oh (1987), Ganesan (1994), Morgan and } \\
\text { Hunt (1994), Kalwani and Narayandas (1995), Min et al. } \\
\text { (2005), Ryu, Park, and Min (2007), Wang, Siu, and Barnes } \\
\text { (2008), Hornibrook, Fearne, and Lazzarin (2009), Chen et al. } \\
\text { (2011), Nyaga and Whipple (2011), Prajogo and Olhager } \\
\text { (2012), Ramanathan and Gunasekaran (2014) }\end{array}$ \\
\hline
\end{tabular}




\section{Measurement Scale Development}

\section{Instrument design}

To ensure that research instruments are reliable and valid, scale development involves creating and testing the content of items, and because developing new scales is inefficient, literature reviews were undertaken to identify existing scales which could be used or adapted. Initial searches identified 76 items that included constructs involving collaboration which may also describe the relationship between shippers and shipping companies (Saunders, Lewis, and Thornhill 2016) (Appendix).

To sift incipient items and ensure practicality within the context of broader shipping industry SCs, six experts from coastal shipping and five from ocean-shipping were invited to discard any items that they felt were inappropriate in the shipping industry. Instructions were to delete redundant and irrelevant items and to integrate items having similar or the same meaning. Items were deleted if $70 \%$ of respondents agreed, as were all items with unclear meanings caused by expansive, abstract, or ambiguous words regardless of the deletion agreement rate. Q-sort methods were adopted to identify the convergent and discriminant validity of scales and may be deployed for scale development if subjective concepts or constructs create reliability and validity issues; they are also conducive to finding concepts which have not been firmly established and to developing new scales (Boon-itt and Paul 2005; Ekinci and Riley 1999). Q-sort procedures were explained, and respondents were asked to enunciate which construct is most closely connected to each scale item or which matching cannot be determined (Segars and Grover 1998). A group of definitions of each construct is created from literature review or experts' remarks and a group of statements apparently representing those definitions is described (Ekinci and Riley 1999). In relation to this technique, the following criteria determine whether a definition exists or not (Ekinci and Riley 1999; Boon-itt and Paul 2005): when a definition can be reasonably explained by at least 
two statements on which over 70 percent of the sample agree, it can be confirmed that the definition exists. Regarding the agreement rate of subjects, Greenberg (1986) proposed a more restrictive 75 percent agreement rate. The results of Q-sorting cannot be generalised to the population if the technique is not followed by confirmatory factor analysis (Ekinci and Riley, 1999; Boon-itt and Paul, 2005). Therefore, this technique should not be regarded as a complete analysis but as a preliminary method in the process of scale development (Ekinci and Riley, 1999).

Two rounds of Q-sorting engaged 21 experts including five director-level civil servants, five members of Korea Shipowners' Association for ocean-going shipping, four members of Korea Shipping Association for coastal shipping, five members of Korea Maritime Institute and two professors of shipping, to select items which best measure a construct. The constructs offered were: Transparency, Fairness, Mutuality, Trust and Sustainability. A "not-applicable" (n/a) category avoided compulsion to associate any item with a named construct. Finally, pilot tests engaged 31 experts in refining the draft questionnaire and evaluating the validity of questions and reliability of planned additional data collection (Saunders, Lewis, and Thornhill 2016). When measures are developed or borrowed using multiple sources, a pre-test for the same types of respondents as in the population of interest should be conducted to screen the adequacy of items (Hair et al 2014). With regard to sample size for a pilot test, responses from 10 to 200 (Saunders, Lewis, and Thornhill 2016) or 30 responses (Lombard, Snyder-Duch, and Bracken 2002) were recommended. Testing with the full sample depends on whether the reliability level acquired through a pilot test is adequate (Lombard, Snyder-Duch, and Bracken 2002). 


\section{Deletion of irrelevant and unclear items instrument design}

Sixteen incipient items were considered inapplicable to shipping logistics (Table 2). For example, items 29 and 31 respectively recorded $73 \%$ and $82 \%$ deletion agreement rates. Some experts suggested that inventory management and demand forecasts are entirely under the control of shippers and inapplicable to SCs. Some indicated that item 48 is inapplicable to shipping because shippers do not share information about their competitors with shipping companies and there is, and never will be, any such case. Items $11,33,34,36$ and 43 were felt unlikely to ever apply in shipping.

Table 2. Deletion of items not applicable to the shipping industry

\begin{tabular}{clc}
\hline $\mathrm{N}$ & \multicolumn{1}{c}{ Items } & ARID \\
\hline 11 & Our firm develops performance metrics and the resulting incentive together with shippers & 73 \\
16 & $\begin{array}{l}\text { Shippers are willing to take responsibility for any damages resulting from their employees } \\
\text { misbehaviour }\end{array}$ & 73 \\
29 & Shippers develop demand forecasts jointly with our firm & 73 \\
30 & Shippers share delivery plans and decide on optimal delivery quantity jointly with our firm & 73 \\
31 & Shippers manage inventory jointly with our firm & 82 \\
33 & Shippers share their facilities and equipment with our firm & 82 \\
34 & Shippers share their knowledge, skill, and technology with our firm & 82 \\
36 & Shippers invest in other resources to support the relationship with our firm & 91 \\
39 & Shippers and our firm are willing to operate alliance teams to solve problems jointly & 91 \\
43 & Shippers determine rewards according to the contribution jointly with our firm & 82 \\
44 & Shippers continue to update key goals (targets) jointly with our firm & 82 \\
45 & Shippers search and acquire new and relevant knowledge jointly with our firm & 73 \\
46 & Shippers assimilate and apply relevant knowledge jointly with our firm & 73 \\
48 & Shippers learn of the intentions and capabilities of competitors jointly with our firm & 73 \\
49 & Our shippers are like a friend to us & 82 \\
53 & We believe our shippers do not mislead our firm & 73 \\
\hline Note. ARID: Agreement rate of item deletion (\%)
\end{tabular}


Seventeen further items were deleted (Table 3) including items 2, 7, and 37 with expansive meanings; items 13, 14, 15, and 50 with abstract meanings; and items 12, 21, 24, 28, 51 55, 56 58, 62 and 67 due to ambiguity. Ambiguity agreement rates for deletion of items 56 and 58 were $64 \%$ and $27 \%$ respectively, as experts queried the meanings of "sincere apology and dishonesty" and “taking advantage of'. Items 13, 14, and 15 were intended to identify how well shippers observe their own ethics and rules concerning commercial transactions, but because of ambiguity concerning which "code of conduct" was being referred to, these items were deleted. Item 24 was considered impracticable because shipping companies are not willing to share any additional rewards and benefits with shippers and vice versa. Items 61, 63 and 64 were initially intended to measure the competence of shippers but discarded when some experts dubbed them irrelevant to research aims.

Table 3. Deletion of items with expansive, abstract, and ambiguous meanings

\begin{tabular}{clc}
\hline $\mathrm{N}$ & \multicolumn{1}{c}{ Items } & ARID \\
\hline 2 & Shippers provide any information which might help our firm & 55 \\
7 & Shippers pay attention to our firm's comments & 18 \\
12 & Our firm adjusts cooperative and collaborative schedules together with shippers & 36 \\
13 & Shippers train their employees through a code of conduct & 55 \\
14 & We believe the employees of shippers observe well the code of conduct & 64 \\
15 & Shippers take actions actively to promote a code of conduct & 45 \\
21 & Shippers try to guarantee incentives commensurate with our firm's investment and risk & 64 \\
24 & Shippers share any additional rewards and benefits with our firm & 64 \\
28 & Shippers agree on the importance of improvements in the delivery & 18 \\
37 & Shippers try to resolve any conflicts jointly with our firm & 45 \\
50 & We feel our shippers have been on our side & 64 \\
51 & We feel a sense of loyalty to our shippers & 64 \\
55 & Even though our shippers give lame explanation, we are confident that our shippers are telling the truth & 64 \\
56 & Shippers are willing to give their sincere apologies for their dishonesty & 64 \\
58 & We rely on our shippers not taking advantage of our firm & 27 \\
62 & We believe that our shippers fulfil their business obligations & 45 \\
67 & We feel that our firm is important to our shippers & 18 \\
\hline Note. ARID: Agreement rate of item deletion (\%) &
\end{tabular}


Three eliminated items, considered very important for measuring the collaborative attitude of shippers, were later readopted. According to an expert's suggestion that the item is ambiguous and needs to be more specific, item 62 was amended to: "we believe that shippers fulfil their contractual obligations" to evaluate the extent to which shipping companies trust the competence of shippers. Despite respectively $82 \%$ and $91 \%$ agreement rates for deletion, items 33 and 36 are very important to measure the attitude of shippers towards shipping companies. In 2009, the author interviewed representatives of shipping company A and its shipper B. Both companies agreed that B provided A with docks for delivery of its freight and guaranteed a bank loan for the procurement of a vessel of A for ten years. Thanks to the support of B, A could focus on effective and safe delivery of B's freight. For this reason, items 33 and 36 were reselected. Respectively, they were amended to "shippers are willing to share their facilities and equipment such as their docks, cranes, delivery vehicles with our firm (if shippers have the facilities and equipment)" and "shippers are willing to provide financial support such as guarantee of a bank loan required for procurement of vessels of our firm (if shippers have such financial capabilities).”

\section{Deletion of redundant and overlapping items}

Where an item has a similar or the same meaning as another item which encompasses it, the original item was considered redundant and deleted. Items 3, 4, 20, 26, 42, 54, 57, 72 were considered redundant (Table 4). For instance, items 3, 4 and 1 are partially similar as relevant and timely information (item 1) can subsume effective information about events or changes (item 3) and shippers' feedback (item 4). Item 41 can incorporate item 42 in that the contribution of shipping companies is necessarily measured by their performance. 


\section{Table 4. Deletion of redundant items}

\begin{tabular}{cl}
\hline $\mathrm{N}$ & \multicolumn{1}{c}{ Items } \\
\hline 3 & Shippers keep our firm informed about events or changes that may affect our firm (a subset of 1) \\
4 & Shippers provide feedback on our delivery services (a subset of 1) \\
20 & $\begin{array}{l}\text { Disputes between shippers and our firm are smoothly settled by the regulations or laws related to business } \\
\text { transaction (a subset of 19) }\end{array}$ \\
26 & Shippers and our firm understand each other's goals, priorities, roles (a subset of 27) \\
42 & Shippers measure the contribution of our firm jointly with our firm (a subset of 41) \\
54 & Our shippers always gives us honest information (a subset of 60) \\
57 & We rely on our shippers keeping their promises (a subset of 62) \\
72 & The shippers regard our relationship as a long-term alliance (similar meaning with 70) \\
\hline
\end{tabular}

Where two items overlap, both were merged into one new quasi synonymous item. Twenty such items were merged into nine (Table 5). Items 59 and 60 were merged into: "we rely on the attention and willingness of shippers to maintain a good relationship with our firm" because top management and the working group of a shipper are recognizable within one entity, "the shipper", regardless of the hierarchical position within the shipper group. Items 74 and 75 were merged into: "shippers try to share new business plans or ideas and expand new markets (including a foreign market) jointly with our firm" because as a new market, a foreign market may represent new business plans or ideas.

\section{Table 5. Merging of overlapping items}

\begin{tabular}{ll}
\hline \multicolumn{1}{c}{ Overlapping items } & \multicolumn{1}{c}{ New statement } \\
\hline 5 and 6 & $\begin{array}{l}\text { Shippers keep in frequent contact with our firm through various channels } \\
\text { Shippers settle cooperative and collaborative implementation plans or objectives by prior } \\
\text { agreements with our firm }\end{array}$ \\
18 and 19 & $\begin{array}{l}\text { Shippers observe well the general regulations related to business transactions such as standard } \\
\text { form of contract and the laws related to fair trade such as the Fair Trade Act }\end{array}$ \\
25 and 27 & $\begin{array}{l}\text { Shippers agree on the importance of cooperation and collaboration with our firm and shippers } \\
\text { and our firm both understand each other's products, processes and services well }\end{array}$ \\
40 and 47 & $\begin{array}{l}\text { Shippers identify customer needs related to delivery and try to improve the delivery quality } \\
\text { jointly with our firm }\end{array}$ \\
59 and 60 & $\begin{array}{l}\text { We rely on the attention and willingness of shippers to maintain a good relationship with our } \\
\text { firm }\end{array}$ \\
65,66 and 68 & We benefit from and are satisfied with the relationship with shippers
\end{tabular}




\section{Results}

\section{First round Q-sorting}

Q-sort techniques were adopted to establish key constructs (Table 6). First round Q-sorting revealed poor agreement rates for the constructs Fairness, Mutuality, Trust, and Sustainability. Only

Transparency met test criteria and can thus be identified as "exists", because items IT1 and IT3 obtained $70 \%$ and $75 \%$ agreement respectively. Some respondents struggled to distinguish between items assumed to represent Trust and Sustainability as well as Fairness and Mutuality. The abstract and general explanation of a construct prevented respondents from understanding clearly the exact meaning of the construct. Consequently, the respondents could not properly undertake the matching between constructs and items. Careful attention should have been paid to the selection of words in items to avoid confusion. More detailed explanations of constructs and cautious selection of words in items can increase the possibility of existence of the constructs rather than discarding them.

\section{Table 6. First round Q-sort}

\begin{tabular}{|c|c|c|c|}
\hline IN & Items & $\mathbf{A R}$ & ARS \\
\hline IT1 & Shippers would like to exchange relevant and timely information with our firm & 70 & \multirow{4}{*}{45} \\
\hline IT2 & Shippers would like to keep in frequent contact with our firm through various channels & 25 & \\
\hline IT3 & Shippers would like to make communication with our firm open and two-way & 75 & \\
\hline IT4 & $\begin{array}{l}\text { Shippers would like to settle cooperative and collaborative implementation plans or objectives by } \\
\text { prior agreements with our firm }\end{array}$ & 10 & \\
\hline IF1 & Shippers try not to discriminate our firm against other shipping companies & 85 & \multirow{4}{*}{63} \\
\hline IF2 & $\begin{array}{l}\text { Shippers try to observe well the general regulations related to business transactions such as standard } \\
\text { form of contract and the laws related to fair trade such as the Fair Trade Act }\end{array}$ & 60 & \\
\hline IF3 & Shippers make an effort to guarantee reasonable profits for our firm & 50 & \\
\hline IF4 & $\begin{array}{l}\text { Shippers make an effort to share any additional risks, burden, and costs related to delivery with our } \\
\text { firm }\end{array}$ & 55 & \\
\hline
\end{tabular}




\begin{tabular}{|c|c|c|c|}
\hline IM1 & $\begin{array}{l}\text { Shippers agree on the importance of cooperation and collaboration with our firm and shippers are } \\
\text { willing to understand our firm's services well }\end{array}$ & 55 & \multirow{8}{*}{31} \\
\hline IM2 & $\begin{array}{l}\text { Shippers are willing to decide on availability level of our facilities and equipment jointly with our } \\
\text { firm }\end{array}$ & 75 & \\
\hline IM3 & $\begin{array}{l}\text { Shippers are willing to share their facilities and equipment such as their dock, cranes, delivery } \\
\text { vehicles with our firm (if shippers have such facilities and equipment) }\end{array}$ & 50 & \\
\hline IM4 & Shippers are willing to dedicate personnel to managing the relationship with our firm & 15 & \\
\hline IM5 & $\begin{array}{l}\text { Shippers are willing to provide financial support such as guarantee of a bank loan required for } \\
\text { procurement of vessels of our firm (if shippers have such financial capabilities) }\end{array}$ & 10 & \\
\hline IM6 & Shippers are willing to listen to our firm's difficulties and to help our firm deal with the difficulties & 20 & \\
\hline IM7 & Shippers are willing to review the performance of our firm on a regular basis jointly with our firm & 45 & \\
\hline IM8 & $\begin{array}{l}\text { Shippers are willing to identify customer needs related to delivery and to improve the delivery } \\
\text { quality jointly with our firm }\end{array}$ & 50 & \\
\hline ITr1 & We feel a bond with our shippers & 60 & \multirow{4}{*}{50} \\
\hline ITr2 & We rely on the attention and willingness of shippers to maintain a good relationship with our firm & 45 & \\
\hline ITr3 & We believe that shippers fulfil their contractual obligations & 90 & \\
\hline ITr4 & We benefit from and are satisfied with the relationship with shippers & 5 & \\
\hline IS1 & We believe the relationship with shippers is stable & 70 & \multirow{4}{*}{44} \\
\hline IS2 & We believe the relationship with shippers will last for a long time and strengthen over time & 55 & \\
\hline IS3 & We have experienced the expansion of business with the help of shippers & 25 & \\
\hline IS4 & $\begin{array}{l}\text { Shippers try to share new business plans or ideas and expand new markets (including foreign } \\
\text { market) jointly with our firm }\end{array}$ & 25 & \\
\hline
\end{tabular}

Improvements to increase the agreement rate for a second round of Q-sorting (Table 7)

included revising some statements due to unclear wording and where correct classification was

under $50 \%$, deletion or replacement by new items. For example, IT2 ("shippers would like to keep

in frequent contact with our firm through various channels") obtained $25 \%$ agreement, being

confused with Sustainability because of the expression "keep in contact". The item was deleted and

substituted by item T2 ("shippers and our firm communicate smoothly with each other through

various channels") to reveal clearly the construct of Transparency. Similar processing was applied

to other revised items because Q-sorting is undertaken to improve content adequacy through the

item refinement process. 


\section{Table 7. Comparison between initial and revised items after round one Q-sorting}

\begin{tabular}{|c|c|c|c|}
\hline IN & The first round Q-sorting & NN & Revised items \\
\hline IT1 & Revised into T1 & T1 & Shippers exchange relevant and timely information with our firm \\
\hline IT2 & $\begin{array}{l}\text { LAR (confused with sustainability) and } \\
\text { Unclear } \rightarrow \text { Revised into T2 }\end{array}$ & $\mathrm{T} 2$ & $\begin{array}{l}\text { Shippers and our firm communicate smoothly with each other } \\
\text { through various channels }\end{array}$ \\
\hline IT3 & Revised into $\mathrm{T} 3$ & $\mathrm{~T} 3$ & Shippers make communication with our firm open and two-way \\
\hline IT4 & $\begin{array}{l}\text { LAR (confused with mutuality) and } \\
\text { Unclear } \rightarrow \text { Separated into T4, M5 }\end{array}$ & $\mathrm{T} 4$ & $\begin{array}{l}\text { The cooperative and collaborative relationship between shippers and } \\
\text { our firm is understood clearly and transparently through prior } \\
\text { agreements }\end{array}$ \\
\hline IF1 & Revised into F1 & F1 & $\begin{array}{l}\text { Shippers do not discriminate our firm against other shipping } \\
\text { companies }\end{array}$ \\
\hline IF2 & Revised into F2 & $\mathrm{F} 2$ & $\begin{array}{l}\text { Shippers try to comply with the regulations related to business } \\
\text { transactions such as standard form of contract and the laws related } \\
\text { to fair trade such as the Fair Trade Act for fair trade with our firm }\end{array}$ \\
\hline IF3 & LAR and unclear $\rightarrow$ Revised into F3 & F3 & $\begin{array}{l}\text { Shippers make an effort to guarantee reasonable and just profits for } \\
\text { our firm }\end{array}$ \\
\hline IF4 & Revised into F4 & F4 & $\begin{array}{l}\text { Shippers make an effort to bear reasonably and justly any additional } \\
\text { risks, burden, and costs related to delivery with our firm }\end{array}$ \\
\hline IM1 & Unclear $\rightarrow$ Revised into M1 & M1 & $\begin{array}{l}\text { Overall, shippers understand our firm's services well and are willing } \\
\text { to provide any necessary assistance }\end{array}$ \\
\hline IM2 & Revised into M6 & M2 & $\begin{array}{l}\text { Shippers are willing to provide their facilities and equipment such } \\
\text { as their dock, cranes, delivery vehicles with our firm (if shippers } \\
\text { have such facilities and equipment) }\end{array}$ \\
\hline IM3 & LAR and unclear $\rightarrow$ Revised into M2 & M3 & $\begin{array}{l}\text { Shippers are willing to provide financial support such as guarantee } \\
\text { of a bank loan required for procurement of vessels for our firm (if } \\
\text { shippers have such financial capabilities) }\end{array}$ \\
\hline IM4 & $\begin{array}{l}\text { LAR (not-applicable, confused with } \\
\text { sustainability) and unclear } \rightarrow \text { Deleted }\end{array}$ & M4 & $\begin{array}{l}\text { Shippers are willing to assist our firm in overcoming the difficulties } \\
\text { when our firm is faced with any difficulties }\end{array}$ \\
\hline IM5 & LAR but no change $\rightarrow \mathrm{M} 3$ & M5 & $\begin{array}{l}\text { Shippers and our firm, as equal business partners, settle together } \\
\text { common cooperative and collaborative implementation plans or } \\
\text { objectives }\end{array}$ \\
\hline IM6 & $\begin{array}{l}\text { LAR (confused with sustainability) and } \\
\text { unclear } \rightarrow \text { Revised into M4 }\end{array}$ & M6 & $\begin{array}{l}\text { Shippers and our firm, as equal business partners, decide together on } \\
\text { availability level of our facilities and equipment }\end{array}$ \\
\hline IM7 & LAR and unclear $\rightarrow$ Revised into M8 & M7 & $\begin{array}{l}\text { Shippers and our firm, as equal business partners, identify together } \\
\text { customer needs related to delivery and try to improve the delivery } \\
\text { quality jointly }\end{array}$ \\
\hline IM8 & LAR and unclear $\rightarrow$ Revised into M7 & M8 & $\begin{array}{l}\text { Shippers and our firm, as equal business partners, review together } \\
\text { the performance of our firm }\end{array}$ \\
\hline ITr1 & $\begin{array}{l}\text { Abstract and unclear } \rightarrow \text { Deleted and } \\
\text { replaced by } \operatorname{Tr} 1\end{array}$ & $\operatorname{Tr} 1$ & Overall, shippers are trustworthy \\
\hline ITr2 & $\begin{array}{l}\text { LAR (confused with sustainability) and } \\
\text { unclear } \rightarrow \text { Revised into Tr2 }\end{array}$ & $\operatorname{Tr} 2$ & $\begin{array}{l}\text { We believe the good faith of shippers when it comes to the } \\
\text { relationship between shippers and our firm }\end{array}$ \\
\hline ITr3 & No change & $\operatorname{Tr} 3$ & We believe that shippers fulfil their contractual obligations \\
\hline $\mathrm{ITr} 4$ & $\begin{array}{l}\text { LAR (confused with sustainability) and } \\
\text { unclear } \rightarrow \text { Revised into Tr4 }\end{array}$ & $\operatorname{Tr} 4$ & We believe that shippers benefit our firm \\
\hline IS1 & Revised into S1 & S1 & The relationship between shippers and our firm is stable \\
\hline IS2 & Revised into S2 & $\mathrm{S} 2$ & $\begin{array}{l}\text { The relationship between shippers and our firm will last and } \\
\text { strengthen over time }\end{array}$ \\
\hline IS3 & $\begin{array}{l}\text { LAR(not-applicable) and unclear } \rightarrow \\
\text { Deleted }\end{array}$ & $\mathrm{S} 3$ & $\begin{array}{l}\text { Shippers try to maintain their relationship with our firm such as } \\
\text { developing together new business plans or ideas }\end{array}$ \\
\hline IS4 & $\begin{array}{l}\text { LAR (confused with mutuality) and } \\
\text { unclear } \rightarrow \text { Divided into S3 and S4 }\end{array}$ & S4 & $\begin{array}{l}\text { Shippers try to enhance continuously their relationship with our firm } \\
\text { such as expanding jointly new markets (including foreign markets) }\end{array}$ \\
\hline
\end{tabular}




\section{Second round $Q$-sorting and pilot testing}

Table 8 shows that second round Q-sorting obtained a very strong overall agreement rate of $97 \%$ with all constructs and items satisfying agreement criteria, verifying that the constructs of this research exist and that the discriminant and convergent validity of the constructs are expected to be very high. Furthermore, no additional Q-sorting rounds or extra stages for item refinement are needed.

Table 8. Second round Q-sort

\begin{tabular}{lcccccc}
\hline & Total & T & F & M & Tr & S \\
\hline ARS (\%) & 97 & 100 & 95 & 100 & 100 & 90 \\
NI/NIC & $28 / 28$ & $4 / 4$ & $4 / 4$ & $8 / 8$ & $4 / 4$ & $4 / 4$ \\
\hline Note. ARS: The Agreement Rate of Subjects, NI: The number of items with over $70 \%$ of ARS, NIC: The total number of items in the construct
\end{tabular}

The pilot questionnaire indicated that nothing was unclear or ambiguous and respondents offered no additional comments. Cronbach reliabilities for scales exceeded 0.7, indicating that all scales are internally consistent and robust (Table 9) and verify that reliability levels were adequate (Lombard, Snyder-Duch, and Bracken 2002).

Table 9. Pilot questionnaire construct reliability

\begin{tabular}{cc}
\hline Construct & Cronbach alpha \\
\hline Transparency & 0.925 \\
Fairness & 0.919 \\
Mutuality & 0.972 \\
Trust & 0.960 \\
Sustainability & 0.925 \\
\hline
\end{tabular}




\section{Conclusion}

This research identified an instrument to measure collaboration between shippers and shipping companies, using measurement scales derived initially from SCM literature. The composites and the indicators were adapted to suit the context of shipping logistics through semi-structured interviews with industrial experts, two-rounds of Q-sorting, and pilot testing. The procedures deployed to develop scales are transferable to other sectors, particularly the process of generating 24 final items from 76 initial items by deleting irrelevant, unclear, redundant, and overlapping items. Although the initial 76 items were properly used in other fields and disciplines, the items should cautiously be revisited in the shipping context. Attempts to unquestioningly transfer established measurement items between different academic fields and disciplines are inappropriate and all items must be tested within a context of interest. Measures suitable for phenomena unique to an industry under examination need to be developed (Gundersen, Heide, and Olsson 1996). With regard to Q-sorting, as abstract and general explanation of a construct can cause misunderstanding and confusion of respondents, constructs need to be explained to respondents fully and in detail. The cautious selection of words for items can also help respondents to comprehend the exact meaning of constructs and their corresponding items.

In this study collaboration was defined as a business partnership process whereby partners aim to sustain long-term cooperative relationships based on trust between them. Transparency was identified as comprising exchange of relevant and timely information, smooth communication through various channels, open and two-way communication, and clear setting-up of the relationship by prior agreements. Fairness was recognized as containing no discrimination, the observation of fair trade laws, the guarantee of reasonable and just profits, and reasonable and just bearing of additional burden and risks. Mutuality was verified to involve notions such as 
understanding of the services of the other partner, common implementation plans/objectives, common identification of customer's needs, common performance measurement and providing adequate assistance to overcome any difficulties including financial support. Trust can be measured by trustworthiness, good faith, fulfilment of obligation, and benevolence. Finally, Sustainability is well represented by belief in the continuity of a relationship and willingness to maintain and enhance the relationship.

Because the final instrument scales were derived from the opinions of shipping experts the constructs and items representing collaboration in this research offer shipping policymakers insights into policies which can increase collaboration between shippers and shipping companies. Specifically, forming consultative groups to enhance transparency through focused two-way communication between the parties can be suggested. To promote fairness, government policymakers should consider how they might facilitate reasonable and just profits.

The final items representing collaboration invite further applications in shipping research because the content validity of each dimension and indicator is high. However, the application of items internationally requires them to be re-examined to reflect cultural and legal differences. Additional interviews targeting shipping experts internationally may be required to develop common items, capable of adaptation internationally. Such measures will assist in formulating policies to enhance national advantages or to remedy shortcomings in the field of shipping. Dyadic research comparing shippers' review of the five constructs of collaboration and the final 24 items presented may offer additional insights.

\section{Acknowledgments}

This work was supported by a 2-Year Research Grant of Pusan National University. 
References:

Anderson, J. C., and J.A. Narus. 1990. "A model of distributor firm and manufacturer firm working partnerships". The Journal of Marketing 54 (1), 42-58.

Barratt, M. 2004. "Understanding the meaning of collaboration in the supply chain". Supply Chain Management: An International Journal 9 (1), 30-42.

Bensaou, M. 1997. "Interorganisational cooperation: The role of information technology an empirical comparison of US and Japanese supplier relations". Information Systems Research 8 (2), 107-124.

Boon-itt, S., and H. Paul. 2005. "Measuring supply chain integration - Using the Q-sort technique." In Research Methodologies in Supply Chain Management: In Collaboration with Magnus Westhaus, edited by: Kotzab, H., S. Seuring, M. Müller, and G. Reiner, 47-58. Heidelberg: Physica-Verlag.

Cao, M., M.A. Vonderembse, Q.Zhang, and T.S. Ragu-Nathan. 2010. "Supply chain collaboration: Conceptualisation and instrument development”. International Journal of Production Research 48 (22), 6613-6635.

Cao, M., and Q. Zhang, Q. 2011. "Supply chain collaboration: Impact on collaborative advantage and firm performance". Journal of Operations Management 29 (3), 163-180.

Chen, J. V., D.C. Yen, T. Rajkumar, and N.A. Tomochko. 2011. "The antecedent factors on trust and commitment in supply chain relationships". Computer Standards and Interfaces 33 (3), 262-270.

Cheng, T., and Y. Wu. 2005. "The impact of information sharing in a two-level supply chain with multiple retailers". Journal of the Operational Research Society 56 (10), 1159-1165.

Daugherty, P. J., R.G. Richey, A.S. Roath, S. Min, H. Chen, A.D. Arndt, and S.E. Genchev. 2006. "Is collaboration paying off for firms?" Business Horizons 49 (1), 61-70.

Delai, I., and S. Takahashi. 2011. "Sustainability measurement system: A reference model proposal.” Social Responsibility Journal 7 (3), 438-471. 
Duffy, R., A. Fearne, and S. Hornibrook. 2003. "Measuring distributive and procedural justice: An exploratory investigation of the fairness of retailer-supplier relationships in the UK food industry." British Food Journal 105 (10), 682-694.

Dwyer, F. R., and S. Oh. 1987. "Output sector munificence effects on the internal political economy of marketing channels". Journal of Marketing Research, 24 (4), 347-358.

Dwyer, F. R., P.H. Schurr, and S. Oh. 1987. “Developing buyer-seller relationships”. The Journal of Marketing 51 (2), 11-27.

Ekinci, Y., and M. Riley. 1999. "Measuring hotel quality: Back to basics". International Journal of Contemporary Hospitality Management 11 (6), 287-294.

Eyuboglu, N., S. Ryu, and T. Tellefsen. 2003. "Current and future interdependence". Journal of Marketing Channels 11 (1), 3-26.

Frémont, A. 2008. Empirical Evidence for Integration and Disintegration of Maritime Shipping, Port and Logistics Activities. OECD/ITF Joint Transport Research Centre Discussion Paper. Paris: Organisation for Economic Cooperation and Development.

Fugate, B. S., B. Davis-Sramek, and T.J. Goldsby. 2009. “Operational collaboration between shippers and carriers in the transportation industry". The International Journal of Logistics Management 20 (3), 425-447.

Ganesan, S. 1994. "Determinants of long-term orientation in buyer-seller relationships". The Journal of Marketing 58 (2), 1-19.

Gardner, J. T., M.C. Cooper, and T.G. Noordewier. 1994. "Understanding shipper-carrier and shipper-warehouser relationships: Partnerships revisited”. Journal of Business Logistics 15 (2), 121-143.

Gibson, B. J., S.M. Rutner, S. M., and S.B. Keller. 2002. "Shipper-carrier partnership issues, rankings and satisfaction”. International Journal of Physical Distribution and Logistics Management 32 (8), 669-681.

Gimenez, C., and E. Ventura. 2005. "Logistics-production, logistics-marketing and external integration: Their impact on performance". International Journal of Operations and Production Management 25 (1), 20-38.

Golicic, S. L., 2007. “A comparison of shipper and carrier relationship strength”. International Journal of Physical Distribution and Logistics Management 37 (9), 719-739. 
Griffith, D. A., M.G. Harvey, and R.F. Lusch. 2006. "Social exchange in supply chain relationships: The resulting benefits of procedural and distributive justice". Journal of Operations Management 24 (2), 85-98.

Gundersen, M. G., Heide, M., and Olsson, U. H. 1996. "Hotel guest satisfaction among business travelers: What are the important factors?" The Cornell Hotel and Restaurant Administration Quarterly 37 (2), 72-81.

Hair, J. F., Black, W. C., Babin, B. J., Anderson, R. E. 2014. Multivariate data analysis (Pearson new international edition). Essex: Pearson.

Hardy, C., N. Phillips, and T.B. Lawrence. 2003. "Resources, knowledge and influence: The organisational effects of interorganisational collaboration”. Journal of Management Studies $40(2), 321-347$.

Harland, C., J. Zheng, T. Johnsen, and R. Lamming. 2004. "A conceptual model for researching the creation and operation of supply networks". British Journal of Management 15 (1), 1-21.

Heaver, T. D. 2015. "Increased collaborative relationships in international logistics: Canadian and other national and corporate examples”. Maritime Policy and Management 42 (3), 278-292.

Heide, J. B., and A.S. Miner. 1992. "The shadow of the future: Effects of anticipated interaction and frequency of contact on buyer-seller cooperation”. Academy of Management Journal 35 (2), 265-291.

Hornibrook, S., A. Fearne, and M. Lazzarin, 2009. "Exploring the association between fairness and organisational outcomes in supply chain relationships". International Journal of Retail and Distribution Management 37 (9), 790-803.

Hosoda, T., and S.M. Disney. 2006. "The governing dynamics of supply chains: The impact of altruistic behaviour". Automatica 42 (8), 1301-1309.

Hudnurkar, M., S. Jakhar, and U. Rathod. 2014. "Factors affecting collaboration in supply chain: A literature review". Procedia-Social and Behavioral Sciences 133, 189-202.

Jayaraman, V., A.D. Ross, and A. Agarwal. 2008. "Role of information technology and collaboration in reverse logistics supply chains". International Journal of Logistics: Research and Applications 11 (6), 409-425.

Kalwani, M. U., and N. Narayandas. 1995. “Long-term manufacturer-supplier relationships: Do they pay off for supplier firms?" Journal of Marketing 59 (1), 1-16. 
Kim, K. K., S.H. Park, S.Y. Ryoo, and S.K., Park. 2010. "Inter-organisational cooperation in buyersupplier relationships: Both perspectives”. Journal of Business Research 63 (8), 863-869.

Kleinsorge, I. K., P.B. Schary, and R.D. Tanner. 1991. “The shipper-carrier partnership: A new tool for performance". Journal of Business Logistics 12 (2), 35-57.

K.M.I. 2017. Study on enhancing the competitiveness of container shipping industry through the structural improvements: Basic research. December. Busan: Korean Maritime Institute.

K.M.I. 2018. Weekly focus on shipping market. Busan: Korean Maritime Institute.

Kogut, B. 1988. "Joint ventures: Theoretical and empirical perspectives”. Strategic Management Journal 9 (4), 319-332.

Konovsky, M.A. 2000. "Understanding procedural justice and its impact on business organisations”. Journal of Management 26 (3), 489-511.

Kumar, G., and R. Nath Banerjee. 2014. "Supply chain collaboration index: An instrument to measure the depth of collaboration". Benchmarking: An International Journal 21 (2), 184204.

Kumar, N., L.K. Scheer, and J-B.E. Steenkamp. 1995. "The effects of supplier fairness on vulnerable resellers". Journal of Marketing Research 32 (1), 54-65.

Kuo, S. Y., P.C. Lin, and C.S. Lu. 2017. "The effects of dynamic capabilities, service capabilities, competitive advantage, and organizational performance in container shipping”. Transportation Research Part A: Policy and Practice 95, 356-371.

Kwon, I. W. G., and T. Suh. 2004. "Factors affecting the level of trust and commitment in supply chain relationships". Journal of Supply Chain Management 40 (1), 4-14.

Lam, J. S. L. 2011. "Patterns of maritime supply chains: Slot capacity analysis". Journal of Transport Geography 19 (2), 366-374.

Lam, J. S. L, and L. Zhang. 2014. "Enhanced logistics service provider framework for higher integration and efficiency in maritime logistics". International Journal of Logistics Research and Applications 17 (2): 89-113.

Lane, C. 2000. "Introduction: Theories and issues in the study of trust". In Trust Within and Between Organisations edited by C. Lane and R. Bachmann, 1-30. Oxford: Oxford University Press. 
Li, L. 2012. "Effects of enterprise technology on supply chain collaboration: Analysis of Chinalinked supply chain”. Enterprise Information Systems 6 (1), 55-77.

Lombard, M., J. Snyder-Duch, and C.C. Bracken. 2002. "Content analysis in mass communication: Assessment and reporting of intercoder reliability". Human Communication Research 28 (4), 587-604.

Lusch, R. F., and J.R. Brown. 1996. "Interdependency, contracting, and relational behavior in marketing channels". Journal of Marketing 60 (4), 19-38.

Malhotra, A., S. Gosain, and O.A.E. 2005. "Absorptive capacity configurations in supply chains: Gearing for partner-enabled market knowledge creation”. MIS Quarterly 29 (1), 145-187.

Maloni, M. J., and M.E. Brown. 2006. "Corporate social responsibility in the supply chain: An application in the food industry". Journal of Business Ethics 68 (1), 35-52.

Maloni, M. J., D.M. Gligor, and I.N. Lagoudis. 2016. "Linking ocean container carrier capabilities to shipper-carrier relationships: a case study". Maritime Policy and Management 43 (8), 959-975.

Mason, R., and R. Nair. 2012. "Strategic flexibility capabilities in the container liner shipping sector". Production Planning and Control 24 (7), 640-651.

Mei, Z., and J. Dinwoodie. 2005. "Electronic shipping documentation in China's international supply chains". Supply Chain Management: An International Journal 10 (3), 198-205.

Mentzer, J. T., J.H. Foggin, and S.L. Golicic. 2000. "Collaboration: The enablers, impediments, and benefits". Supply Chain Management Review 4 (4), 52-58.

Midoro, R., E. Musso, and F. Parola. 2005. "Maritime liner shipping and the stevedoring industry: Market structure and competition strategies". Maritime Policy and Management 32 (2), 89106.

Min, S., A.S. Roath, P.J. Daugherty, S.E. Genchev, H. Chen, A.D. Arndt, and R.G. Richey. 2005. "Supply chain collaboration: What's happening?" The International Journal of Logistics Management 16 (2), 237-256.

Mohr, J., and J.R. Nevin. 1990. "Communication strategies in marketing channels: A theoretical perspective”. Journal of Marketing 54 (4), 36-51.

Morgan, R. M., and S.D. Hunt. 1994. "The commitment-trust theory of relationship marketing". The Journal of Marketing 58 (3), 20-38. 
Nassirnia, P., and R. Robinson. 2013. "Supply chain integration and chain efficiency: The importance of changing perspective toward whole chain integration". Journal of Applied Sciences and Engineering Management 1 (1), 13-23.

Notteboom, T., J-P. Rodrigue, and G. De Monie. 2010. "The organisational and geographical ramifications of the 2008-09 financial crisis on the maritime shipping and port industries". In Integrating Seaports and Trade Corridors edited by P. Hall, R. McCalla, C. Comtois and B. Slack, 31-46. Aldershot: Ashgate.

Nyaga, G. N., and J.M. Whipple. 2011. "Relationship quality and performance outcomes: Achieving a sustainable competitive advantage”. Journal of Business Logistics 32 (4), 345360.

Panayides, P.M., and D-W., Song. "Port integration in global supply chains: measures and implications for maritime logistics”. International Journal of Logistics Research and Applications 12 (2), 133-145.

Park, N. K., J.M. Mezias, and J. Song. 2004. “A resource-based view of strategic alliances and firm value in the electronic marketplace”. Journal of Management 30 (1), 7-27.

Prajogo, D., and J. Olhager. 2012. "Supply chain integration and performance: The effects of longterm relationships, information technology and sharing, and logistics integration". International Journal of Production Economics 135 (1), 514-522.

Ramanathan, U., and A. Gunasekaran. 2014. "Supply chain collaboration: Impact of success in long-term partnerships". International Journal of Production Economics 147 (Part B), 252259.

Richey, R. G., A.S. Roath, J.M. Whipple, and S.E. Fawcett. 2010. "Exploring a governance theory of supply chain management: Barriers and facilitators to integration”. Journal of Business Logistics 31 (1), 237-256.

Ryu, S., J.E. Park and S. Min. 2007. "Factors of determining long-term orientation in interfirm relationships". Journal of Business Research 60 (12), 1225-1233.

Sahin, F., and E.P. Robinson. 2002. "Flow coordination and information sharing in supply chains: Review, implications, and directions for future research.” Decision Sciences 33 (4), $505-$ 536. 
Saunders, M., P. Lewis, and A. Thornhill. 2016. Research Methods for Business Students (7th edition). Harlow: Pearson.

Segars, A. H., and V. Grover. 1998. "Strategic information systems planning success: An investigation of the construct and its measurement". MIS Quarterly 22 (2), 139-163.

Seo, Y. J., J. Dinwoodie, and M. Roe. 2016. "The influence of supply chain collaboration on collaborative advantage and port performance in maritime logistics". International Journal of Logistics Research and Applications 19 (6), 562-582.

Seo, Y. J., J. Dinwoodie, and M. Roe. 2015. "Measures of supply chain collaboration in container logistics". Maritime Economics and Logistics 17 (3), 292-314.

Simatupang, T. M., and R. Sridharan, R. 2005. "The collaboration index: A measure for supply chain collaboration". International Journal of Physical Distribution and Logistics Management 35 (1), 4-62.

Simatupang, T. M., and R. Sridharan, R., 2004. "A benchmarking scheme for supply chain collaboration". Benchmarking: An International Journal 11 (1), 9-30.

Slack, B., C. Comtois, and R. McCalla. 2002. "Strategic alliances in the container shipping industry: A global perspective". Maritime Policy and Management 29 (1), 65-76.

Slone, R. E. 2004. “Leading a supply chain turnaround”. Harvard Business Review 82 (10), 114121.

Song, D.-W., and E-S. Lee. 2012. "Coopetitive networks, knowledge acquisition and maritime logistics value". International Journal of Logistics Research and Applications 15 (1), 15-35.

Song, D.-W., and P.M. Panayides, 2008. "Global supply chain and port/terminal: Integration and competitiveness". Maritime Policy and Management 35 (1), 73-87.

Stank, T. P., S.B. Keller, and D.J. Closs. 2001. "Performance benefits of supply chain logistical integration". Transportation Journal 41 (2/3), 32-46.

Stopford, M. 2009. Maritime Economics (3rd edition). New York: Routledge.

Talley, W. K., and M. Ng. 2013. "Maritime transport chain choice by carriers, ports and shippers". International Journal of Production Economics 142 (2), 311-316.

Thomson, A. M., J.L. Perry, and T.K. Miller. 2009. “Conceptualizing and measuring collaboration”. Journal of Public Administration Research and Theory 19 (1), 23-56. 
UNCTAD. 2016. Review of Maritime Transport, 2016: UNCTAD/RMT/2016. Geneva: United Nations Convention on Trade and Development.

Wandfluh, M., E. Hofmann, E., and P. Schoensleben. 2016. "Financing buyer-supplier dyads: an empirical analysis on financial collaboration in the supply chain". International Journal of Logistics Research and Applications 19 (3), 200-217.

Wang, C. L., N.Y.M. Siu, and B.R. Barnes. 2008. "The significance of trust and renqing in the long-term orientation of Chinese business-to-business relationships". Industrial Marketing Management, 37 (7), 819-824.

Zsidisin, G. A., M.D. Voss, and M. Schlosser. 2007. "Shipper-carrier relationships and their effect on carrier performance". Transportation Journal 46 (2), 5-18. 


\section{Appendix}

Compilation of initial items

\begin{tabular}{|c|c|}
\hline $\mathbf{N}$ & Items \\
\hline 1 & Shippers would like to exchange relevant and timely information with our firm \\
\hline 2 & Shippers provide any information which might help our firm \\
\hline 3 & Shippers keep our firm informed about events or changes that may affect our firm \\
\hline 4 & Shippers provide feedback on our delivery services \\
\hline 5 & Shippers and our firm keep frequent contact on a regular basis \\
\hline 6 & Many different channels to communicate between shippers and our firm exist \\
\hline 7 & Shippers pay attention to our firm's comments \\
\hline 8 & Communication between shippers and our firm is open and two-way \\
\hline 9 & Cooperative and collaborative goals or objectives are settled by prior agreements with shippers \\
\hline 10 & Our firm arranges cooperative and collaborative implementation plans together with shippers \\
\hline 11 & Our firm develops performance metrics and the resulting incentive together with shippers \\
\hline 12 & Our firm adjusts cooperative and collaborative schedules together with shippers \\
\hline 13 & Shippers train their employees through a code of conduct \\
\hline 14 & We believe the employees of shippers observe well the code of conduct \\
\hline 15 & Shippers take actions actively to promote a code of conduct \\
\hline 16 & Shippers are willing to take responsibility for any damages resulting from their employees' misbehaviours \\
\hline 17 & Shippers do not discriminate our firm against other shipping companies \\
\hline 18 & Shippers observe well the general regulations related to business transaction such as standard form of contract \\
\hline 19 & Shippers observe well the laws related to fair trade such as the Fair Trade Act \\
\hline 20 & $\begin{array}{l}\text { Disputes between shippers and our firm are smoothly settled by the regulations or laws related to business } \\
\text { transaction }\end{array}$ \\
\hline 21 & Shippers try to guarantee incentives commensurate with our firm's investment and risk \\
\hline 22 & Shippers try to guarantee reasonable profits for our firm \\
\hline 23 & Shippers share any additional risks, burden, and costs related to delivery with our firm \\
\hline 24 & Shippers share any additional rewards and benefits with our firm \\
\hline 25 & Shippers agree on the importance of cooperation and collaboration with our firm \\
\hline 26 & Shippers and our firm understand each other's goals, priorities, roles \\
\hline 27 & Shippers and our firm understand each other's products, processes, and services \\
\hline 28 & Shippers agree on the importance of improvements in the delivery \\
\hline 29 & Shippers develop demand forecasts jointly with our firm \\
\hline 30 & Shippers share delivery plans and decide on optimal delivery quantity jointly with our firm \\
\hline 31 & Shippers manage inventory jointly with our firm \\
\hline 32 & Shippers decide on availability level of our facilities and equipment jointly with our firm \\
\hline 33 & Shippers share their facilities and equipment with our firm \\
\hline 34 & Shippers share their knowledge, skill, and technology with our firm \\
\hline 35 & Shippers dedicate personnel to managing the relationship with our firm \\
\hline 36 & Shippers invest in other resources to support the relationship with our firm \\
\hline 37 & Shippers try to resolve any conflicts jointly with our firm \\
\hline 38 & Shippers listen to our firm's difficulties and try to help our firm deal with the difficulties \\
\hline 39 & Shippers and our firm are willing to operate alliance teams to solve problems jointly \\
\hline 40 & Shippers try to improve the delivery quality jointly with our firm \\
\hline 41 & Shippers review the performance of our firm on a regular basis jointly with our firm \\
\hline 42 & Shippers measure the contribution of our firm jointly with our firm \\
\hline 43 & Shippers determine rewards according to the contribution jointly with our firm \\
\hline 44 & Shippers continue to update key goals (targets) jointly with our firm \\
\hline 45 & Shippers search and acquire new and relevant knowledge jointly with our firm \\
\hline 46 & Shippers assimilate and apply relevant knowledge jointly with our firm \\
\hline 47 & Shippers identify customer needs related to delivery jointly with our firm \\
\hline 48 & Shippers learn of the intentions and capabilities of competitors jointly with our firm \\
\hline 49 & shippers are like a friend to us \\
\hline
\end{tabular}




\begin{tabular}{ll}
\hline $\mathbf{N}$ & \\
\hline 50 & We feel our shippers have been on our side \\
51 & We feel a sense of loyalty to our shippers \\
52 & We feel a bond with our shippers \\
53 & We believe our shippers do not mislead our firm \\
54 & Our shippers always gives us honest information \\
55 & Even though our shippers give lame explanation, we are confident that our shippers are telling the truth \\
56 & Shippers are willing to give their sincere apologies for their dishonesty \\
57 & We rely on our shippers keeping their promises \\
58 & We rely on our shippers not taking advantage of our firm \\
59 & We rely on the attention and willingness of top management of our shippers to maintain a good relationships with \\
& our firm \\
60 & We rely on the attention and willingness of working group of our shippers to maintain a good relationship with \\
& our firm \\
61 & We believe that our shippers can carry out important projects related to our activities \\
62 & We believe that our shippers fulfil their business obligations \\
63 & We believe that our shippers can do things which we cannot do \\
64 & We believe that our shippers hold successful reputations in their fields \\
65 & We feel happy that we can work with our shippers \\
66 & We feel that we benefit from the relationship with our shippers \\
67 & We feel that our firm is important to our shippers \\
68 & We feel that our shippers are satisfying the needs of our firm \\
69 & We believe our relationship with our shippers is strong and stable \\
70 & We expect our relationship with our shippers to last for a long time \\
71 & We expect the relationship with our shippers to strengthen over time \\
72 & The shippers regard our relationship as a long-term alliance \\
73 & We have experienced and expect the expansion of business with the help of our shippers \\
74 & Shippers discover new markets jointly with our firm \\
75 & Shippers share new business plans or ideas with our firm \\
76 & Shippers try to expand overseas jointly with our firm \\
\hline
\end{tabular}

